\title{
EVALUASI KINERJA CAMPURAN BETON ASPAL LAPIS AUS (AC-WC) MEMAKAI LIMBAH ABU-CPO SEBAGAI FILLER
}

\author{
Blank (11pt) \\ Blank (11pt)
}

\author{
Yelvi ${ }^{1}$ dan Mukhlis ${ }^{2}$
}

\section{Blank (11pt)}

Energy source for crude palm oil making process are usually from fry up palm fiber and nut shell for which produce ash as residue. Those residualhave never been optimally used, thus this study suggested to optimiseash of palm fiber and nut shell asfiller for asphalt mix. This study aims to evaluate impact ofadding ash of palm fiber and nut shell to asphalt mix performance in terms of it stability and durability and also to compare the performance of asphalt mixwith and without ash of palm fiber and nut shell using Marshall method. This study found that stability of asphalt mix with AB50\% and AS50\% ash of palm fiber and nut shell has likely increased and after reaching its maximum value, stability has steadily decreased, while its durability has gradually decreased. The highest and lowest IKS were found at asphalt mix with AB100\% and AS100\% respectively. KAO has gradually risen along with increase of percentage of ash of palm fiber and nut shell (5,6\% KAO for AB100\% and AB50\% and AS50\% and 5,8\% KAO for AS100\%). To conclude, this result showed that asphalt mix with filler using ash of palm fiber and nut shellneeds high concentrate asphalt in order to meet volumetric asphalt mix characteristic and Marshall.

Kata kunci : ash of palm fiber and nut shell, stability, IKS.

\section{PETUNJUK U MUM}

Penggunaan aspal sebagai bahan pengikat pada perkerasan jalan sudah digunakan secara luas, namun proses pembuatan bahan aspal itu sendiri membutuhkan investasi yang sangat besar sehingga harga aspal menjadi mahal dan selain itu ketersediaan di alam juga terbatas dan suatu saat akan menjadi langka. Berbagai penelitian masih terus dilakukan untuk mencari bahan alternatif pengganti aspal atau bahan tambah lain sebagai upaya meningkatkan kinerja aspal.

Luas Areal perkebunan sawit di Indonesia terus bertumbuh dengan pesat, demikian pula produksi dan ekspor minyak sawitnya. Luas areal tanaman kelapa sawit meningkat dari 290 ribu Ha pada tahun 1980 menjadi 5.9 juta hektar pada tahun 2006 atau meningkat 20 kali lipat. Dalam kurun waktuyang sama, produksinya, berupa CPO (minyak kelapa sawit mentah) dan CPKO (minyak inti sawit mentah), meningkat 17 kali lipat dari 0,85 juta ton menjadi 14,4 juta ton. Untuk propinsi Sumatera Barat 65.388 Ha menghasilkan CPO sebanyak 765.430 ton. Selain CPO pengolahan ini juga menghasilkan limbah/produk samping, antara lain: limbah cair (POME=Palm Oil Mill Effluent), cangkang sawit, fiber/sabut, dan tandan kosong kelapa sawit. Sabut dan cangkang umumnya digunakan sebagai bahan bakar boiler. Uap dari boiler dimanfaatkan untuk menghasilkan energi listrik dan untuk merebus TBS sebelum diolah di dalam pabrik. Limbah dari proses tersebut

\footnotetext{
${ }^{1}$ Staf Pengajar Jurusan Teknik Sipil Politeknik Negeri Padang

${ }^{2}$ Staf Pengajar Jurusan Teknik Sipil Politeknik Negeri Padang
} 
berupa abu pada boiler. Abu cangkang dan sabut kelapa sawit merupakan biomass dengan kandungan silika $(\mathrm{SiO})$ yang potensial dimanfaatkan. Pembakaran cangkang dan serat buah (sabut) menghasilkan kerak yang keras berwarna putih - keabuan akibat pembakaran dengan suhu yang tinggi dengan kandungan silika 71,14 \%. Berdasarkan data pabrik kelapa sawit PTPN NUSANTARA II menunjukan lebih dari 100 ton/minggunya dihasilkan cangkang dan serabut buah sawit yang akan menghasilkan 3 - 5 ton/minggu kerak boiler (abu). Namun selama ini, belum dimanfaatkan secara optimal.

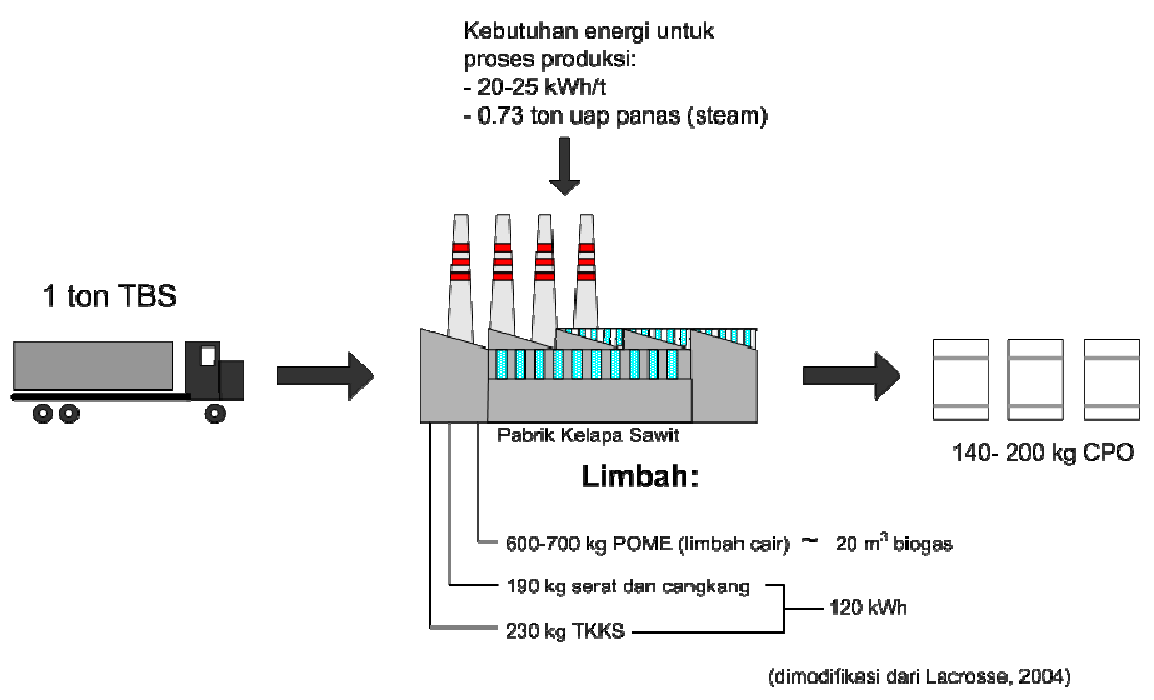

Gambar 1. proses pengolahan sawit

Laston Lapis Aus (AC-Wearing Course) adalah merupakan lapisan paling atas dari struktur perkerasan yang berhubungan langsung dengan roda kendaraan, mempunyai tekstur yang lebih halus dibandingkan dengan Laston Lapis Pondasi (AC-Binder Course). Disamping sebagai pendukung beban lalu lintas, lapisan ini juga mempunyai fungsi sebagai pelindung konstruksi dibawahnya dari kerusakan akibat pengaruh air dan cuaca, sebagai lapisan aus dan menyediakan permukaan jalan yang rata dan tidak licin. Akibat beban lalu lintas berat dan temperatur yang tinggi mengakibatkan fungsi dari lapisan ini tidak berjalan sebagaimana mestinya sehingga terjadi kerusakan-kusakan di permukaan jalan dan menerus kerusakan konstruksi dibawahnya.

Untuk memenuhi fungsi seperti yang dikemukana diatas terutama pendukung beban lalu lintas diperlukan Laston Lapis Aus (AC-Wearing Course) yang mampu menahan beban lalu lintas berat pada temperatur yang tinggi. Denggan menggunakan filler abu dari cangkang dan sabut kelapa sawit ( Limbah CPO ) pada campuran Beton Aspal Lapis Aus (AC-Wearing Course) kiranya dapat menjawab permasalahan ini. Penggunaan abu dari cakang dan sabut kelapa sawit sebagai filler diharapakan mampu meningkatkan kinerja campuran aspal beton.

Untuk itu penelitian ini menjadikan abu tersebut salah satu bahan alternatif sebagai filler karena ketersedian material pengisi (filler) dari debu batu hasil pemecahan batu (stone crusher) kadang tidak cukup dalam penggunaanya, ini karena produksi debu batu sangat terbatas sementara kebutuhan material untuk jalan cukup besar. Beberapa penelitian menunjukkan bahwa didalam abu tersebut terdapat beberapa unsur kimia silica, dimana unsur tersebut memungkinkan akan memiliki peranan sebagai penguat (reinforcement) dalam campuran asapal sehingga diharapkan dapat meningkatkan kinerja campuran. Abu hasil pembakaran cakang dan sabut kelapa sawit disaring dengan saringan No. $200(0,075 \mathrm{~mm})$ dan hasilnya dijadikan sebagai filler. Pada penelitian ini abu tersebut akan dijadikan filler yaitu pada kadar $50 \%$ dan $100 \%$. 
Tujuan dari penelitian ini adalah Mengevaluasi karakteristik Marshall dan Kepadatan Mutlak (Refusal Density) dari campuran dengan mengunakan filler Abu - CPO (FA-0, FA-50, FA-100) dan campuran dengan filler abu batu (FB-100).

\section{STUDI PUSTAKA}

Sandra Mude (2012), Perancangan Laboratorium Pemanfaatan Abu Serat Kelapa Sawit Sebagai Filler Pada Campuran HRS - BC kurang memiliki ketahanan terhadap crack (retak), hal ini terlihat dari nilai Tensile Strength Ratio (TSR) yang dihasilkan untuk variasi 1, 2, 3, 4 dan 5 masingmasing sebesar $89 \%, 77 \%, 74 \%, 66 \%$ dan $64 \%$.

Tunggul Wijaya Panggabean (2012), Perancangan Laboratorium Pemanfaatan Abu Cangkang Kelapa Sawit Sebagai Filler Pada Campuran HRS - BC, mempunyai IRS $>90 \%$, ini menandakan campuran ini tahan terhadap air dan perubahan temperatur. Campuran HRS-Base dengan filler Abu Cakang Kelapa Sawit mempunyai TSR yang memenuhi syarat (> 80\%) adalah pada variasi $25 \%$ filler abu cakang sawit (82\%). Hal ini menandakan bahwa pada variasi $25 \%$ filler abu cakang sawit, campuran masih memenuhi minimum kuat tarik tak langsung.

Penelitian - penelitian tentang aspal modifikasi ini dilakukan juga oleh Marlina (2007) yaitu tentang pengaruh mikro karbon sebagai bahan tambah aspal pada campuran Lataston Lapis Aus (HRS-WC). Mikro karbon yang digunakan bahan bakunya berasal dari bahan - bahan sisa yang dibakar dan dikarbonisasi yang kemudian akan ditambahkan kedalam aspal dengan beberapa variasi persentase pada campuran Lapis Tipis Aspal Beton (Lataston) Lapis Aus (HRS-WC). Kadar mikro karbon yang ditambahkan adalah 5\%,10\% dan 15\%, dimana hasil yang diperoleh pada penelitian tersebut adalah menyebabkan titik lembek naik, aspal kurang peka terhadap suhu seiring dengan meningkatnya penambahan mikro karbon. Pada kinerja campuran penambahan mikro karbon menyebabkan stabilitas naik dan mempunyai ketahanan deformasi sedangkan durabilitas menurun. Pada penelitian tersebut diperoleh bahwa penambahan mikro karbon meningkatan kinerja aspal dan campuran, namun ada juga beberapa parameter yang menurun sehingga diperlukan pengujian lebih lanjut yang diantaranya adalah pengujian dengan penambahan mikro karbon yang lebih kecil dari $10 \%$.

Rusfiandi (2004) melakukan penelitian tentang pengaruh modifikasi aspal dengan damar (resin) pada beton aspal. Pada penelitian tersebut pengaruh penambahan \% damar (resin) menyebabkan beton aspal mempunyai stabilitas yang lebih tinggi dibandingkan dengan beton aspal tanpa menggunakan damar (resin). Disamping itu penambahan \% damar (resin) pada aspal menyebabkan aspal lebih keras dan tidak peka terhadap suhu. Selain itu penelitian lanjut yang dilakukan oleh Rusfiandi (2004) yaitu Pengetesan uji Kuat Tarik Tak Langsung dengan menggunakan alat Indirect Tensile Test diperoleh bahwa Nilai Tensile Strength pada beton aspal yang menggunakan penambahan \% damar (resin) cenderung meningkat, namun pada suhu tertentu yaitu antara $45^{\circ} \mathrm{C}$ dan $60^{\circ} \mathrm{C}$ Nilai Tensile Strength tidak menunjukan nilai yang begitu berarti.

\section{METODOLOGI}

Dari penelitian ini diharapkan akan didapatkan alternatif bahan untuk dapat meningkatkan kinerja aspal dalam campuran beton aspal lapis aus. Fishbone Diagram Penelitian diperlihatkan pada Gambar 2. Prosedur pengujian yang digunkan mengacu pada Satandar Nasional Indonesia (SNI), American Association of stat Higway and Transportation official (AASHTO), American Society for Testing and Material (ASTM) dan British Standard (BS). Penelitian ini terdiri dari tahapan 1) pengujian sifat properties material agregat, 2) pengujian sifat properties material aspal, 3) pengujian kimia abu dan aspal, 4) pengujian campuran aspal.

VOLUME 9 NO. 2, OKTOBER 2013 | 33 


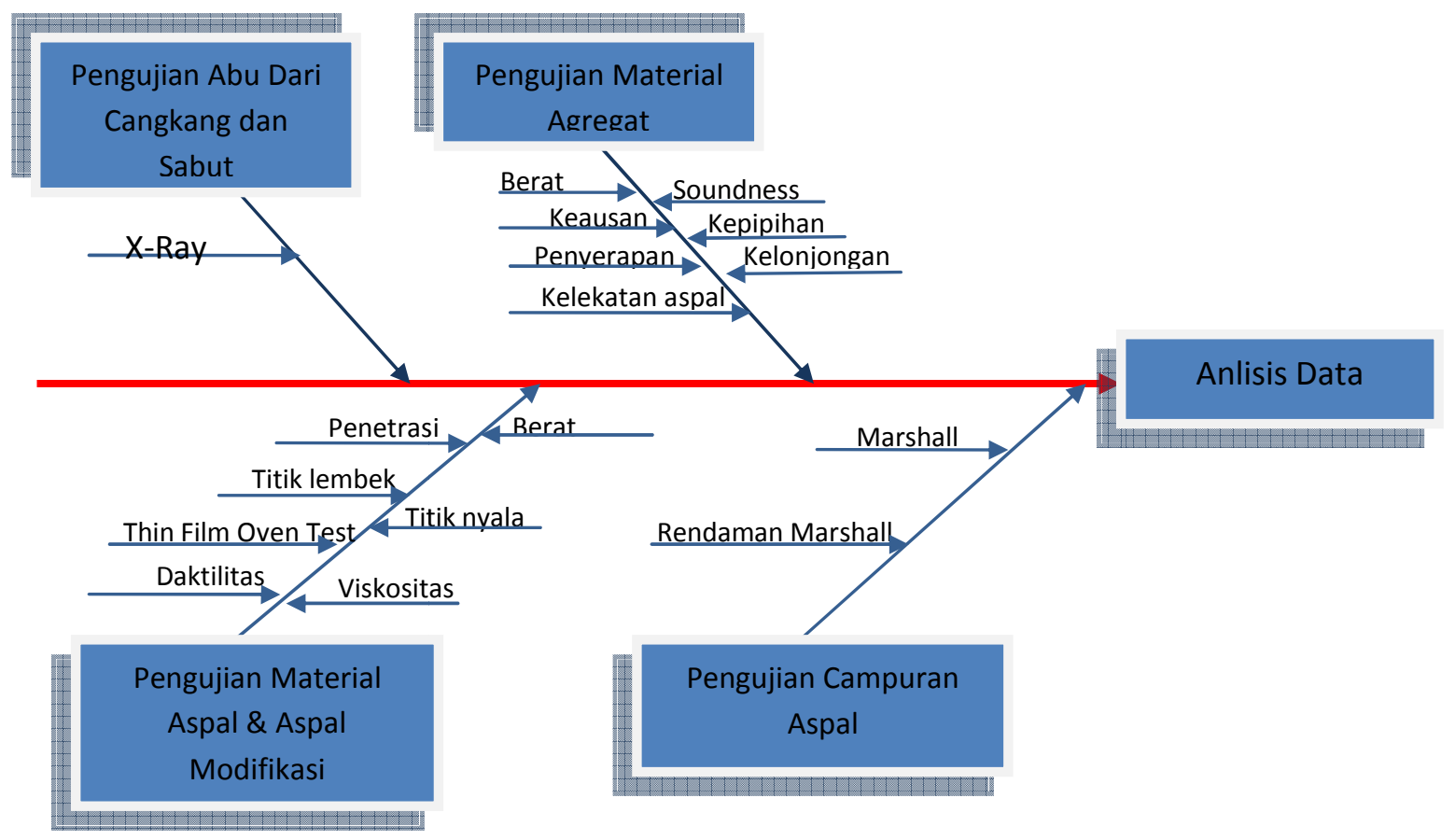

Gambar 2 . Fishbone Diagram penelitian

\section{HASIL DAN PEMBAHASAN}

Pembahasan dilakukan berdasarkan hasil pengujian Marshall sebagai berikut.

\subsection{Karakteritik Volumetrik}

Volumetrik campuran yang berperan penting dalam pengujian Marshall yaitu VIM, VMA, VFA, dimana parameter ini sangat berkaitan dengan nilai kepadatan (density) dan sangat menentukan nilai Kadar Aspal Optimum (KAO).

\section{a. Kepadatan}

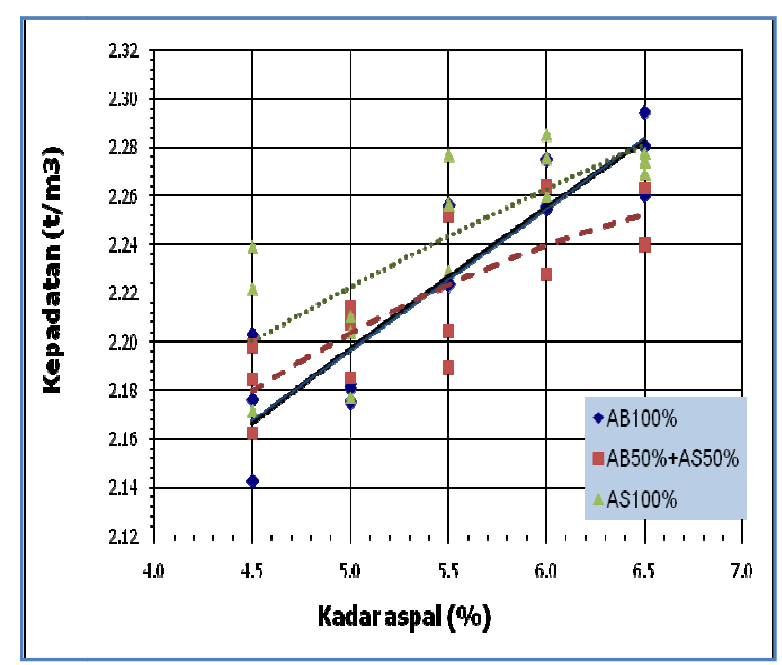

Gambar 3. Perbandingan Kepadatan Terhadap Kadar Aspal 
Kepadatan adalah berat campuran yang diukur tiap satuan volume (The Asphalt Institute, 1983). Kepadatan merupakan tingkat kerapatan campuran setelah campuran dipadatkan. Kepadatan campuran beraspal meningkat seiring dengan meningkatnya kadar aspal hingga mencapai nilai maksimum dan setelah itu nilainya akan turun.

Pada Gambar 3. menunjukkan bahwa dengan filler (Abu batu50\% + filler Abu Sawit50\%) menyebabkan kepadatan campuran cenderung semakin menurun dan ini merupakan kepadan terendah dari ketiga campuran, dimana kepadatan tertinggi terdapat pada campuran dengan filler AS100\% . Penurunan kepadatan terjadi pada campuran dengan filler (Abu batu50\% + filler Abu Sawit50\%), dimana hal ini diakibatkan oleh volume campuran yang bertambah seiring meningkatnya volume aspal dalam campuran. Selain akibat dari volume campuran yang bertambah, penurunan kepadatan terjadi akibat dari berat jenis campuran padat bulk $(\mathrm{Gmb})$ yang menurun sedangkan berat jenis campuran maksimum teoritis $(\mathrm{Gmm})$ semakin naik.

\section{b. Rongga udara dalam campuran (VIM)}

Rongga udara dalam campuran (VIM) sangat berhubungan dengan keawetan campuran. Campuran dengan nilai VIM yang rendah akan lebih kedap air dan cenderung mempunyai ketahanan yang lebih baik terhadap efek penuaan aspal (ageing) dan pengelupasan butir (striping). Namun nilai VIM yang terlalu rendah akan menyebabkan bleeding dan campuran rentan terhadap alur plastis (rutting), dimana hal ini disebabkan karena tidak tersedianya ruang yang cukup untuk menampung ekspansi aspal akibat kenaikan temperatur perkerasan dan pemadatan lanjutan oleh lalu lintas. Sebaliknya campuran dengan nilai VIM yang terlalu besar mengakibatkan meningkatnya proses oksidasi aspal yang dapat mempercepat penuaan aspal dan menurunkan durabilitas campuran. Oleh karena itu nilai VIM menurut spesifikasi Departemen Pekerjaan Umum untuk jenis campuran dibatasi 3,5\% sampai dengan 5,5\% untuk menjamin ketahanan campuran terhadap faktor penyebab kerusakan diatas. Kandungan rongga dalam campuran (VIM) sangat dipengaruhi oleh berat jenis campuran. Campuran yang mempunyai berat jenis bulk $(\mathrm{Gmb})$ yang relatif besar mendekati nilai berat jenis maksimum teoritis (Gmm) akan memberikan VIM yang lebih kecil.

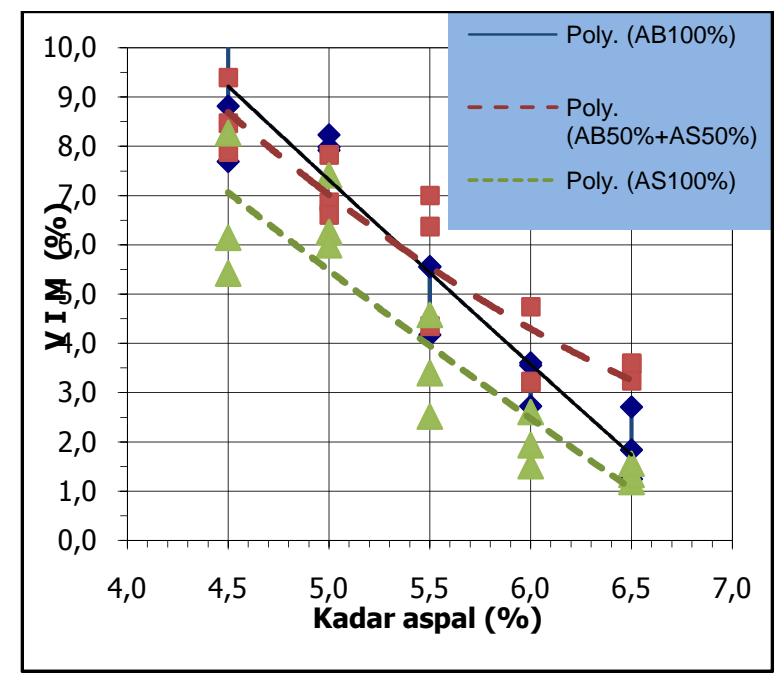

Gambar 4. Perbandingan VIM Terhadap Kadar Aspal

Berdasarkan Gambar 4. terlihat bahwa pada kadar aspal yang sama, nilai VIM pada campuran semakin rendah seiring dengan bertambahnya prosentase filler abu cangakang sawit (AS). Campuran yang mempunyai kadar filler abu cangakang sawit (AS) yang besar menyebabkan nilai VIM semakin kecil. Hal ini disebabkan karena nilai VIM dipengaruhi oleh berat jenis campuran maksimum teoritis $(\mathrm{Gmm})$, dimana nilai berat jenis campuran maksimum teoritis ini dipengaruhi 
oleh berat jenis aspal, berat jenis efektif agregat dan proporsinya dalam campuran. Semakin kecil nilai berat jenis campuran maksimum teoritis maka nilai VIM yang akan diperoleh semakin kecil. Penggunaan filler abu cangkang sawit sampai $100 \%$ dalam campuran menyebabkan nilai berat jenis campuran maksimum teoritis menjadi lebih kecil sehingga nilai VIM jadi lebih kecil, dimana pada Gambar 4. terlihat bahwa VIM semakin turun seiring dengan meningkatnya penambahan filler abu cangkang sawit dalam campuran. VIM terendah terdapat pada campuran dengan AS100\%, dimana hal ini tejadi dikarenakan campuran mempunyai nilai berat jenis campuran maksimum teoritis $(\mathrm{Gmm})$ terendah.

Pada Gambar 4. juga terlihat bahwa pada kadar aspal yang sama yaitu 6,5\%, untuk campuran AS100\% berat jenis campuran maksimum teoritis (Gmm) adalah $2,31 \mathrm{t} / \mathrm{m} 3$ yang merupakan nilai terendah dibandingkan campuran lainnya. Selain berat jenis campuran maksimum teoritis $(\mathrm{Gmm})$, nilai VIM juga sangat dipengaruhi oleh kepadatan, dimana semakin besar kepadatan maka VIM yang diperoleh akan semakin kecil. Kepadatan pada campuran AS100\% adalah 2,305 t/m3 merupakan kepadatan dengan nilai terbesar dan juga mempunyai nilai VIM terkecil, yaitu 1,36\% apabila dibandingkan dengan campuran - campuran lainnya.

\section{c. Rongga diantara mineral agregat (VMA)}

Rongga diantara mineral agregat (VMA) adalah ruang diantara partikel agregat suatu campuran beraspal meliputi rongga udara (VIM) dan rongga yang terisi aspal efektif (VFA) yang dinyatakan sebagai persen volume bulk campuran dengan batasan nilai VMA minimal 15\%. Nilai VMA akan menentukan jumlah potensi ruang yang akan ditempati oleh aspal sehingga VMA sangat mempengaruhi keawetan campuran. VMA dipengaruhi oleh berat jenis bulk campuran padat $(\mathrm{Gmb})$ yang setara dengan nilai kepadatan campuran. Ada kaitan antara nilai VMA dan VIM karena sama - sama dipengaruhi oleh nilai kepadatan, dimana nilai VMA akan mengecil seperti juga nilai VIM bila kepadatan campuran meningkat.

Pada Gambar 5. menunjukan bahwa semakin besar persentase filler abu cangkang sawit dalam campuran, maka semakin kecil VMA yang dihasilkan. VMA sangat dipengaruhi oleh berat jenis padat bulk campuran $(\mathrm{Gmb})$ dan juga volume campuran. Pada gambar terlihat bahwa campuran dengan filler AS100\% memiliki VMA terkecil sedangkan VMA terbesar terdapat pada campuran dengan filler $\mathrm{AB} 100 \%$

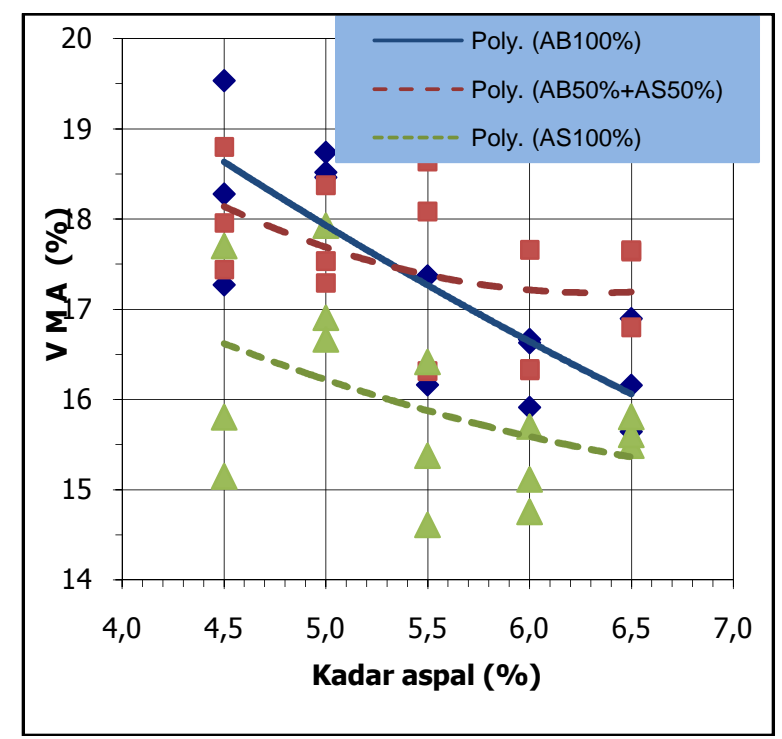

Gambar 5. Perbandingan VMA Terhadap Kadar Aspal 
Berdasarkan Gambar 5. terlihat bahwa pada kadar aspal yang sama yaitu 4,5\% campuran dengan filler AB100 memiliki nilai VMA terbesar $(18,36 \%)$ dan juga berat jenis padat bulk campuran $(\mathrm{Gmb}=2,174 \mathrm{t} / \mathrm{m} 3)$ terkecil, dimana hal ini menunjukkan adanya hubungan antara VMA dengan berat jenis padat bulk campuran (Gmb), yaitu semakin besar nilai VMA dalam campuran maka berat jenis padat bulk campuran $(\mathrm{Gmb})$ semakin menurun. Selain berat jenis padat bulk campuran $(\mathrm{Gmb})$, nilai VMA juga sangat dipengaruhi oleh volume benda uji, dimana seiring dengan meningkatnya penambahan filler Abu cangkang sawit dalam campuran maka volume benda uji bertambah kecil.

\section{d. Rongga terisi aspal (VFB)}

Rongga terisi aspal (VFB) adalah persen rongga yang terdapat di antara partikel agregat (VMA) yang terisi oleh aspal efektif, tidak termasuk aspal yang diserap oleh agregat. Berdasarkan Spesifikasi Umum Perkerasan Aspal Departemen Pekerjaan Umum nilai VFB dibatasi minimal $65 \%$ terhadap VMA. Pengaruh utama VFB dalam perencanaan campuran adalah membatasi nilai VMA dan kadar aspal maksimum.

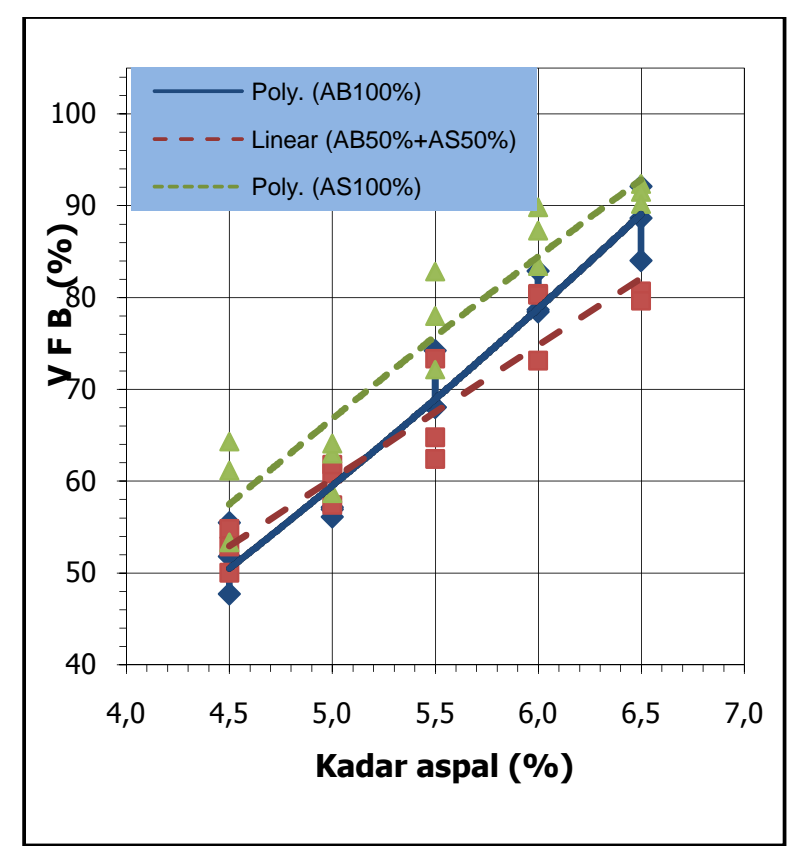

Gambar 6. Perbandingan VFB Terhadap Kadar Aspal

Pada Gambar 6. menunjukkan bahwa pada kadar aspal yang sama nilai VFB cenderung meningkat seiring dengan meningkatnya persentase filler Abu cangkang sawit, dimana hal ini disebabkan karena campuran dengan filler abu cankang sawit memiliki nilai VIM dan VMA yang lebih kecil apabila dibandingkan dengan campuran lainya. Untuk memenuhi persyaratan VFB $\geq 65$ diperlukan kadar aspal yang lebih besar. Setiap campuran memberikan kadar aspal yang berbeda - beda untuk memenuhi persyaratan VFB minimal $65 \%$. Dalam memenuhi VFB $\geq 65$, campuran dengan filler AS100\% membutuhkan aspal yang lebih sedikit dibandingkan dengan campuran - campuran lainnya, dimana hal ini disebabkan oleh:

a. Campuran dengan filler AS100\% mempunyai kepadatan lebih besar dari pada campuran lainnya

b. Campuran dengan filler AS100\% mempunyai nilai VIM dan VMA yang lebih kecil apabila dibandingkan dengan campuran lainnya. 


\subsection{Karakteritik Marshall}

\section{a. Stabilitas}

Stabilitas merupakan suatu ukuran kemampuan campuran untuk memikul beban lalu lintas sampai terjadi kelelehan plastis. Nilai stabilitas akan meningkat seiring dengan meningkatnya kadar aspal, hingga mencapai nilai maksimum dan setelah itu nilainya akan menurun, hal ini menunjukkan bahwa stabilitas maksimum akan dicapai pada suatu nilai kadar aspal tertentu atau Kadar Aspal Optimum. Nilai stabilitas tersebut diukur langsung dari pengujian dengan alat uji Marshall.

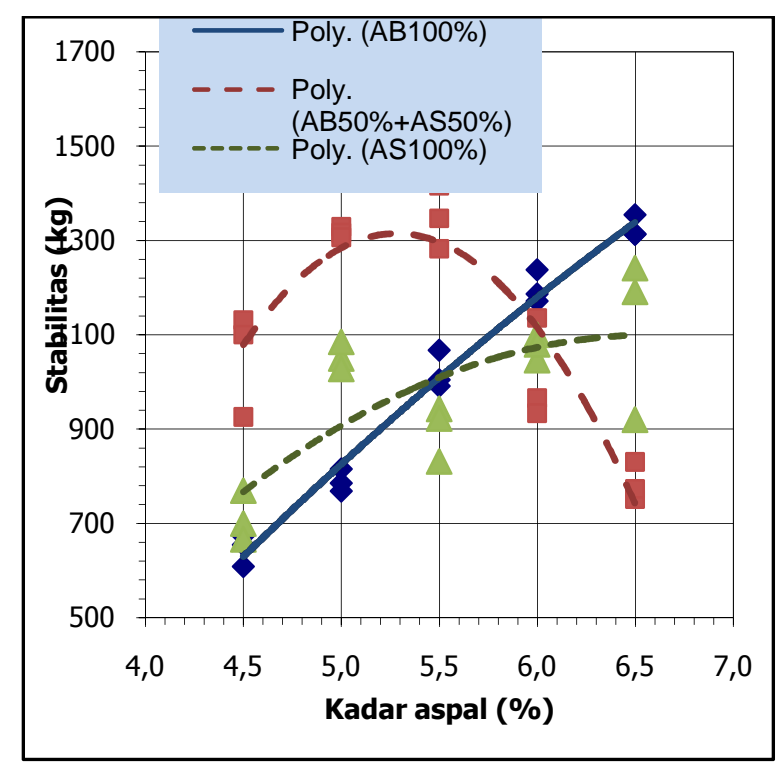

Gambar 7. Perbandingan Stabilitas Terhadap Kadar Aspal

Berdasarkan Gambar 7. terlihat bahwa semakin tinggi filler abu cangkang sawit yang ditambahkan kedalam campuran, maka semakin rendah nilai stabilitas, dimana hal ini disebabkan ikatan mortar dalam campuran yang menggunakan filler abu cangkang sawit tidak kaku dan tidak tahan terhadap perubahan suhu sehingga akan menurunkan nilai kekuatan atau stabilitas jika dibandingkan dengan campuran dengan $\mathrm{AB} 100 \%$. Hal ini mungkin saja terjadi dikarenakan pada suhu tinggi campuran dengan filler abu cangkang sawit (AS100\%) kurang berperan, dimana yang lebih berperan adalah filler abu batu 50\% + filler abu cangkang sawit(50\%) dan agregat. Abu batu dan abu cangkang sawit saling mengisi rongga - rongga dalam campuran sedangkan agregat memberikan interlocking atau gaya gesek antar agregat ketika diberi beban.

\section{b. Kelelehan (Flow)}

Nilai kelelehan (flow) merupakan ukuran kelenturan campuran untuk dapat mengikuti deformasi yang terjadi akibat beban lalu lintas tanpa timbulnya retak dan perubahan volume. Tingkat kelelehan campuran dipengaruhi oleh kadar aspal dalam campuran, temperatur, viskositas aspal, dan bentuk partikel agregat.

Pada Gambar 8. menunjukkan bahwa nilai kelelehan cenderung naik seiring meningkatnya penambahan persentase filler abu cakang sawit pada kadar aspal yang sama, yaitu sampai mencapai titik maksimal pada campuran dengan filler AS100\%. Hal ini bisa saja terjadi dikarenakan pada campuran dengan filler AS100\% mempunyai VMA yang lebih tinggi apabila dibandingkan dengan campuran lainya sehingga pergesekan antara agregat menjadi lebih kecil dan campuran menjadi 
lebih lentur. Kombinasi stabilitas tinggi dengan flow tinggi, membuat campuran tidak mudah mengalami keretakan pada saat diberi beban.

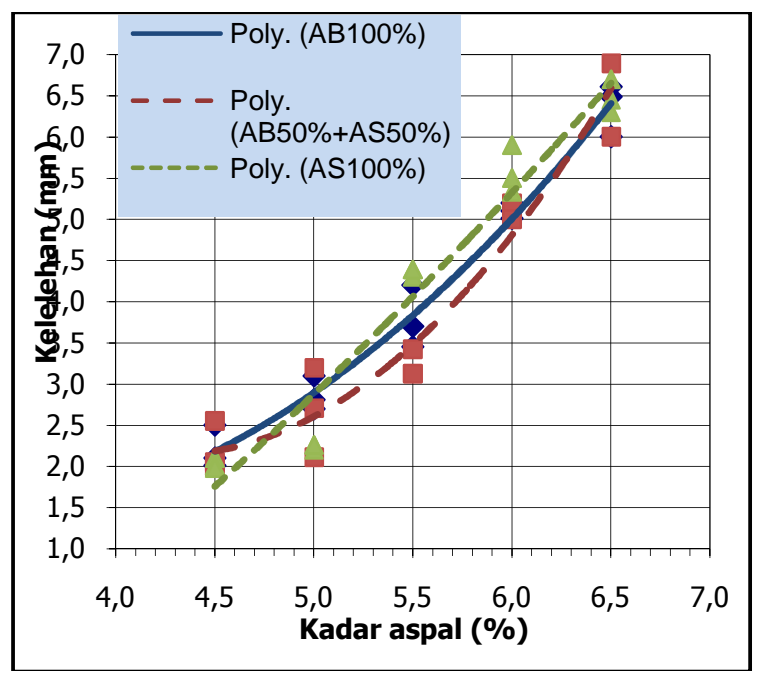

Gambar 8. Perbandingan Kelelehan Terhadap Kadar aspal

\section{c. Hasil Bagi Marshall (MQ)}

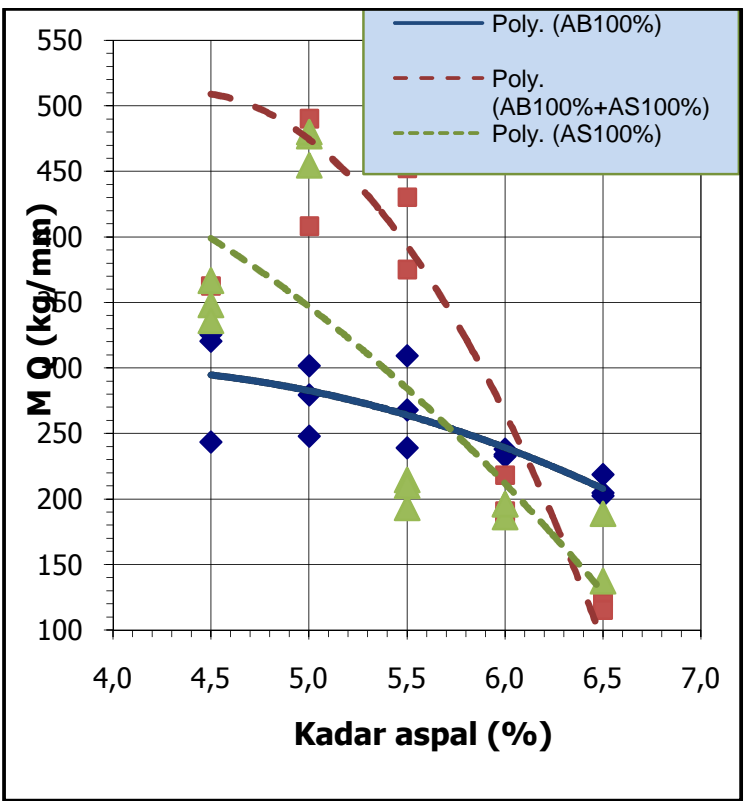

Gambar 9. Perbandingan MQ Terhadap Kadar Aspal

Hasil Bagi Marshall atau Marshall Quotient (MQ) adalah ukuran yang menunjukkan kekakuan campuran, yang merupakan perbandingan antara stabilitas dan kelelehan. Nilai MQ yang tinggi menunjukkan bahwa campuran memiliki kekakuan yang tinggi, namun berpotensi terjadi keretakan. Sebaliknya, nilai MQ yang rendah menunjukkan bahwa campuran rentan terhadap perubahan bentuk atau deformasi permanen.

Pada Gambar 9. terlihat bahwa MQ meningkat seiring dengan meningkatnya penambahan filler abu cakang sawit, dimana hal ini menunjukkan bahwa campuran dengan filler abu batu $50 \%+$ abu cakang sawit 50\% memiliki kekakuan campuran yang lebih tinggi dibandingkan campuran yang 
lain. Berdasarkan kepada Hasil Analisis Marshall Pada Benda Uji Kondisi KAO menunjukkan bahwa nilai Hasil Bagi Marshall (MQ) campuran dengan filler AB50\% +AS50\% merupakan nilai yang paling tinggi, dimana hal ini bisa terjadi karena campuran ini mempunyai nilai stabilitas yang cukup tinggi dan kelelehan yang terkecil jika dibandingkan dengan campuran lainnya. Hal ini bisa saja terjadi karena ketika dalam pengujian pada temperatur tinggi, aspal yang berada dalam campuran kurang berperan sehingga yang lebih berperan adalah filler abu batu dan filler cakang sawit, yang kemudian filler tersebut mengisi rongga - rongga dalam campuran dan menyebabkan campuran menjadi lebih kaku.

\section{KESIMPULAN DAN SARAN}

\subsection{Kesimpulan}

Penggunaan filler abu cakang sawit (limbah-CPO) yang dicampurkan kedalam campuran beraspal memberikan kesimpulan sebagai berikut:

a. Penambahan filler abu cakang sawit 50\% menyebabkan campuran menjadi lebih keras dan kurang peka terhadap perubahan suhu.

b. Kadar Aspal Optimum (KAO) semakin naik seiring dengan meningkatnya persentase filler abu cakang sawit dalam campuran yaitu KAO pada campuran dengan filler (AB100\%) $5,6 \%$, KAO pada campuran dengan filler (AB50\%+AS50\%) 5,6\% dan KAO pada campuran dengan filler AS100\%) adalah 5,8\%. Ini menunjukkan bahwa campuran dengan filler abu cakang sawit membutuhkan kadar aspal yang tinggi untuk memenuhi karakteristik volumetrik campuran dan Marshall.

c. Penambahan filler abu cakang sawit sampai 50\% (AB50\%+AS50\%) dalam campuran menyebabkan nilai stabilitas cenderung naik, namun setelah melewati titik maksimal yaitu pada campuran dengan AS 100\% stabilitas kembali menurun.

d. Hasil Perendaman Marshall menunjukkan bahwa campuran dengan filler abu cakang sawit (AS100\%) mempunyai Indeks Kekuatan Marshall Sisa (IKS) yang lebih kecil dibandingkan dengan campuran lain, namun walaupun demikian Indeks Kekuatan Marshall Sisa (IKS) pada campuran denga filler AB100\%, AB50\%+AS50\% dam AS100\% masih memenuhi persyaratan spesifikasi Departemen Pekerjaan Umum yaitu minimum 75\%.

e. Campuran dengan filler AB50\%+AS50\% memberikan kinerja yang lebih baik dibandingkan dengan campuran - campuran lainnya walaupun berdasarkan stabilitas dan durabilitas belum memberikan hasil yang memuaskan.

f. Hasil secara keseluruhan menunjukkan bahwa campuran dengan filler abu cakang sawit memberikan kinerja yang cukup baik walaupun pada beberapa parameter, seperti halnya pada kinerja durabilitas belum memberikan hasil yang memuaskan.

\subsection{Saran}

Berdasarkan hasil dan pengalaman yang diperoleh selama penelitian, penambahan abu sekam memberikan peningkatan terhadap kinerja aspal maupun campuran, walaupun ada beberapa parameter lainnya yang belum memberikan hasil yang begitu memuaskan, maka untuk itu sebagai saran - saran untuk pengujian lanjut adalah sebagai berikut:

a. Perlu penelitian mengetahui peranan abu cakang sawit sebagai adiktif dalam aspal

b. Perlu penelitian lanjut dengan menggunakan jenis campuran yang berbeda

c. Perlu pengujian lebih lanjut dengan menggunakan alat Wheel Tracking, Dartec dan Modulus Reselient untuk mengetahui pengaruh filler abu cakang sawit dalam campuran terhadap deformasi permanen ,retak lelah yang ditimbulkan akibat beban berulang dan kekakuan campuran. 


\section{DAFTAR KEPUSTAKAAN}

Anonim (2013) http://www.cangkangkelapasawit.com/mengenai-cangkang-sawit/kegunaan-cangkang-sawit

AASHTO (1998), Standar Specifications For Transportation Materials and Method of Sampling and Testing, Washington D.C.

B.S 594 (1992), Hot Rolled Asphalt for Roads and Other Paved Areas, British Standard Institution, London.

Departemen Pekerjaan Umum (1983), Petunjuk Pelaksanaan Lapis Tipis Aspal Beton.

Departemen Pekerjaan Umum (1999), Pedoman Perencanaan Campuran Beraspal Panas dengan Pendekatan Kepadatan Mutlak.

Departemen Pekerjaan Umum (2005), Divisi 6 Perkerasan Aspal Spesifikasi Umum Bidang Jalan dan Jembatan.

Departemen Permukiman dan Prasarana Wilayah (2002), Pelaksanaan Disiminasi Spesifikasi Baru Aspal Panas Dengan Alat PRD.

Harsono, Heru (2002), Pembuatan Silika Amorf dari Limbah Sekam Padi, Jurnal Ilmu Dasar, Fakultas Matematika dan Ilmu Pengetahuan Alam, Universitas Brawijaya.

Haryono, Eddy (1999), Serat Sawit Sebagai Bahan Tambah Pada Campuran Beraspal Bergradasi Senjang, Magister Tesis, Program Sistem dan Teknik Jalan Raya, Institut Teknologi Bandung.

Huang, Yang H (2004), Pavement Analysis and Design, Published by Pearson Prentice-Hall, Inc. New Jersey $279-309$.

Irawan, Her (1992), Pemanfaatan Abu Sekam Padi Untuk Pembuatan Karborundum Melalui Proses Reduksi Karbotermal Dari Silika, Fakultas Matematika dan Ilmu Pengetahuan Alam, Institut Teknologi Bandung.

Ida Zahrina( 2007 ) Pemanfaatan abu sabut dan cangkang sawit Sebagai sumber silika pada sintesis zsm-5

Loebis, B. \& Tobing, P.L. (1989). Potensi pemanfaatan limbah kelapa sawit. Buletin Perkebunan. 20: 49-56.

Marlina, Linda (2007), Pengaruh Mikro Karbon Sebagai Bahan Tambah Aspal Pada Campuran Lapis Aus, Magister Tesis, Program Sistem dan Teknik Jalan Raya, Institut Teknologi Bandung.

Pramono, Agus (1984), Lime And Rice Hull Ash In Soil Stabilization, Magister Tesis, Program Sistem dan Teknik Jalan Raya, Institut Teknologi Bandung.

Rusfiandi, Wandi (2004), Pengaruh Modifikasi Aspal dengan Damar Pada Beton Aspal, Magister Tesis, Program Sistem dan Teknik Jalan Raya, Institut Teknologi Bandung.

Shell Bitumen (1990), The Shell Bitumen Handbook, Shell Bitumen,UK, 89-97.

Standar Nasional Indonesia (1991), Manual Pekerjaan Campuran Beraspal Panas.

Sandra Mude (2012), Perancangan Laboratorium Pemanfaatan Abu Serat Kelapa Sawit Sebagai Filler Pada Campuran HRS - BC.

The Asphalt Institute (1983), Asphalt Technology and Construction Practices, Maryland.

Tunggul Wijaya Panggabean (2012), Perancangan Laboratorium Pemanfaatan Abu Cakang Kelapa Sawit Sebagai Filler Pada Campuran HRS - BC

Yoder, E.J., Witczak, M.W. (1975), Principles of Pavement Design, Second Edition, John Wiley and Sons, Inc, New York, 262-265. 